\title{
Urban design factors involved in the aesthetic as- sessment of newly built environments and their in- corporation into legislation: The case of Istanbul
}

Newly built environments in cities whose features have changed due to neoliberal policies and priorities have often been criticized for their lack of aesthetic qualities. This criticism has made the aesthetic assessment of such environments more important, raising two crucial questions: how such an assessment can be performed, and how it can be incorporated into legislation. This article focuses on both questions in the case of Istanbul by determining and ranking formal aesthetic factors using factor and ANOVA analyses of the results of a survey conducted with three different sampling groups (scholars, designers, and officials) in Istanbul in 2017. The results of the analyses show that scholars' views in evaluating urban formal aesthetics are different from those of officials and designers. In addition, the analyses reveal that "character and identity", "green design", and "incompatibility between identity and design" are three important factors affecting urban formal aesthetics in newly built environments. These results are then followed by a discussion on how these factors can be incorporated into legislation in the case of Istanbul.

Keywords: aesthetic assessment, newly built environment, urban design factors, formal aesthetic parameters, Istanbul, Turkey 


\section{Introduction}

Studies related to urban neoliberalism emphasize how neoliberal policies have led to the reconfiguration of spaces in cities the world over. Under such policies, "competitiveness" is considered indispensable to the economic prospects of a city (Karaman, 2013). Urban space has become one of the most profitable sources of investments, leading cities to adopt aggressive place-marketing strategies to attract capital (Swyngedouw et al., 2002; Kuyucu \& Unsal, 2010). Large-scale (mega) projects, mass housing projects, and the construction of shopping malls, five-star hotels, and business centres began to shape urban environments (Kuyucu \& Unsal, 2010; Özalp \& Erkut, 2016). Newly built environments in cities whose features have been changed due to neoliberal policies and priorities have often been criticized for their lack of aesthetic qualities. This criticism has made discussions of urban aesthetics increasingly important, raising two crucial questions: how to perform aesthetic assessments of newly built environments, and how to incorporate such assessments into legislation. This article focuses on both questions in the case of Istanbul. Various studies in the literature have demonstrated that the aesthetic assessment of the built environment depends on both subjective and formal parameters (Strenberg, 1991; Nasar, 1994). This study, however, takes into consideration only formal aesthetic parameters, using urban design criteria that are more concrete and easily incorporated into legislation.

Istanbul is Turkey's most important economic, cultural, and tourism centre, occupying a strategic location between Asia and Europe. At the same time, Istanbul is a city world-famous for its natural beauty and monuments left over from its status as the capital city of the Roman, Byzantine, and Ottoman empires (Kuban \& Yalçın, 2010). However, Istanbul has undergone radical and dramatic restructuring since the beginning of the 2000s under a neoliberal regime (Lovering \& Turkmen, 2011; Karaman, 2013). This restructuring has been shaped by a construction boom that depends on the real estate and property markets (Balaban, 2012). Istanbul has thus been rapidly losing its unique nature (Barfu Candan \& Ozbay, 2014). The neoliberal policies in force since the 2000s have physically enlarged the city and at the same time led to many new physical, social, environmental, and ecological problems, among which are squatter settlements (Tur. gecekondu), tall mass residential structures and mega projects and their integration into the city, transportation systems and traffic problems, infrastructure, and overcrowded areas. Naturally, Istanbul has also been harmed in terms of urban aesthetics. In particular, the construction boom has seriously damaged the formal aesthetics of the city, especially its skyline (Figure 1). Therefore, the factors affecting urban aesthetics in newly built environments in Istanbul need
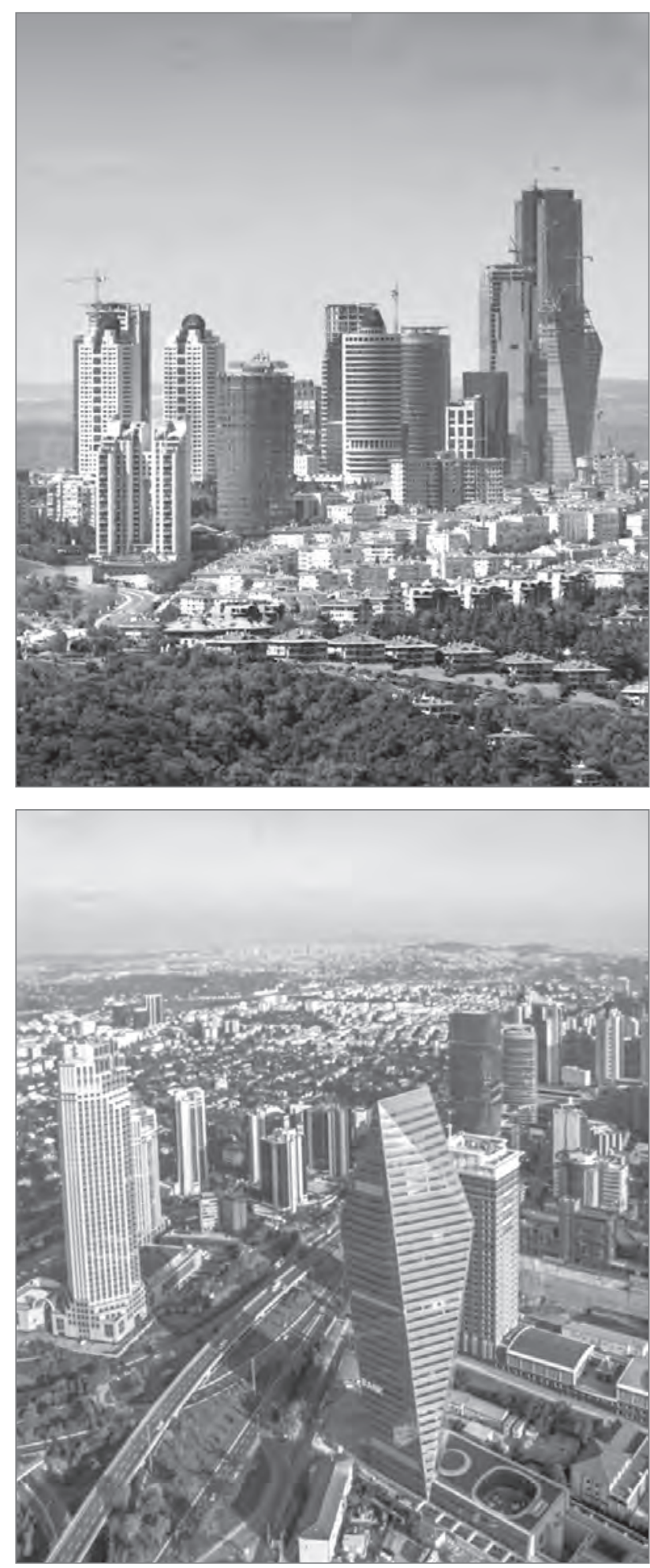

Figure 1: Construction boom in Istanbul (source: GYODER, 2015).

to be determined in order to inform policies that contribute to improving the city's formal aesthetics. This study can be useful for other cities facing the same construction dynamics.

The following section is a review of the literature related to urban aesthetics. The third section of the paper focuses on the 
aesthetic assessment of built environments. The fourth section examines the urban design factors involved in the aesthetic assessment of newly built environments and is divided into four subsections: the first subsection outlines the research design, the second includes data and sampling, the third contains the results of the study's analyses, and the fourth examines the urban design factors involved in the aesthetic assessment of newly built environments in existing legislation. The last full section is devoted to a general evaluation and conclusions.

\section{Literature review: urban aesthetics}

In literature, the definitions, research methodologies, and indicators related to urban aesthetics differ from one study to another, according to the research aim. Despite this diversity in conceptualization, there is a consensus that urban aesthetics is a multidimensional concept. As Teymur (1981: 81) has explained, "aesthetic" is a semantically ubiquitous term. It functions as an adjective to qualify other qualifying terms such as "quality", "dimension", "value", and so on. It is invariably a "positive" adjective. It implies "good", "beautiful", "nice", and not "bad" or "ugly" and so on. "Aesthetic" and "aesthetics" also refer to the appreciation or criticism of the beautiful, the philosophy or science of taste, or the perception of beauty (Norton, 1967; Teymur, 1981). Traditional definitions of aesthetics refer to the perception of beauty in the arts and may imply extreme and intense feelings such as the sublime (Nasar, 1997: 152).

The urban aesthetic is a subjective consideration beyond quantification (Sternberg, 1991: 70). Pehlivanoğlu (2011: 1) describes urban aesthetics as a complex subject that needs to go beyond the evaluation of a city's physical characteristics and requires the consideration of individuals' experiences as a significant part of urban quality. Although some in the literature consider structure and meaning the basis of urban aesthetics, others also take into account the contributions of natural setting, land use, traffic and pedestrian flows, the built form, and people's behavioural patterns. In brief, the defined relationships between buildings and the environment, well-structured spatial transitions, and harmony determine the nature of urban aesthetics (Erdoğan, 2006: 72; Xiangzhan, 2008: 63; Mowla, 2011: 169). These parameters have helped planners understand the multidimensional nature of urban aesthetics.

There are various approaches to the evaluation of aesthetics in urban areas. For example, Nasar (1994: 382) distinguishes between the formal and symbolic aesthetics of a city. The former includes parameters such as shape, proportion, rhythm, scale, complexity, colour, illumination, shadowing, and hierarchy, which describe the physical characteristics of buildings. Symbolic aesthetics is defined by parameters such as the human experience of building exteriors through mediating content variables that are not defined solely by physical attributes. In some studies, urban aesthetic concerns are divided into two spheres: architectural values and urban aesthetics (King, 1997). Whereas architectural aesthetics has more to do with the physical qualities of buildings and the space around them, urban aesthetics comprises a much wider range of values, conditions, and criteria, such as economics, traffic, and pollution. These phenomena, while not necessarily visual, have an impact on how one perceives the city and they play an important role in aesthetic perceptions. Also among these issues are the cultural and social values that a society or community brings to the urban area (King, 1997). According to Onaran (1995: 24), people's aesthetic experience of their surroundings cannot be independent from the meaning they attribute to and the attachments they form with the surrounding environment. Aesthetic substance thus depends on the concepts of the "aesthetic subject", "aesthetic object", and "aesthetic value". The aesthetic object refers to the natural setting, space and mass, surface, and skyline of a city. The dimension, form, location, and distance and direction relations between objects influence the aesthetic values of an urban space (Pehlivanoğlu, 2011: 11). The aesthetic subject is defined as a matter of taste in environmental aesthetics. Similarly, Nasar (1990) describes the evaluation of the urban environmental image as depending on a person's biology, personality, sociocultural experience, adaptation levels, goals, and expectations. Because people are unique, with different senses, needs, and requirements that give shape, meaning, and function to a place, their identification with and perception of a place are also different. Another study has argued that the investigation of urban aesthetics takes place at four levels (Alcock, 1993, cited in Pehlivanoğlu, 2011: 17): aesthetics of proportion, aesthetics of the plan, artistic aesthetics, and social aesthetics. Here, the aesthetics of proportion refers to the reaction of viewers to visual stimuli of high aesthetic quality, the aesthetics of the plan is related to the objective value of the geometrical arrangements of forms such as geometrical hierarchies, artistic aesthetics involves the expression of ideas in an abstract way with the help of urban design, and social aesthetics is concerned with the subjective experience of space (Pehlivanoğlu, 2011: 17).

Urban aesthetics is a multidimensional and complex subject that can be evaluated both formally and symbolically, requiring assessments of individuals' experience, behaviour patterns, and subjective consideration and meaning at the same time as those of physical characteristics, natural setting, land-use, circulation systems, and built forms. Because the aim of this study is to examine urban aesthetics in a way that can be incorporated into urban laws and regulations, only the formal aesthetic parameters are taken into consideration because legislation requires the inclusion of more concrete parameters. 
Therefore, aesthetic considerations such as matters of taste in environmental aesthetics, biology, personality, adaptation levels, goals, expectations, and the social, economic, and cultural circumstances and values that a society brings to the urban area, none of which are defined solely by physical attributes, are excluded from the scope of this study.

\section{Aesthetic assessment of built environments}

Studies on the aesthetic assessment of built environments are quite limited in the literature. Although the aims of most of these studies are almost similar, the methodologies through which they attempt to quantify urban aesthetics vary greatly.

There are some perception-based studies concerning the measurement of the aesthetic quality of the built environment (Strenberg, 1991; Pehlivanoğlu, 2011; Gomeshi \& Mohd Jusan, 2013; Ahmad Nia et al., 2017; Gjerde, 2017). For example, Ahmad Nia et al. (2017) evaluated the aesthetic characteristics of urban spaces from a morphological point of view. In this study, urban aesthetics was quantified through a consideration of the chronological development of urban expansion through a city's history. The study selected four neighbourhoods from different periods of urban growth in a city, using both subjective and physical parameters in evaluating urban aesthetics. According to this research, people's perception of the aesthetics of an urban environment changes along with their aesthetic values and characteristics. Another study (Gjerde, 2017) evaluated the visual aesthetic perceptions of urban streetscapes using surveys conducted with the public and design and planning professionals. Gomeshi et al. (2013) investigated the different aesthetic preferences of architects and non-architects in residential facade designs. Pehlivanoğlu (2011) evaluated perceptions related to the aesthetics of urban public space by considering the relationship between the aesthetic subject, object, and value.

Some studies related to urban aesthetics have focused on the aesthetics of the urban landscape. Sahraoui et al. (2016) examined aesthetic judgements of landscapes using a set of landscape visibility metrics as spatial data in their survey research. In another study (Chen et al., 2009), the aesthetic quality of an urban green space was evaluated using quantitative holistic evaluation techniques. Cats-Baril and Gibson (1987) evaluated landscape aesthetics using design experts.

There are other studies of urban aesthetics based on different perspectives. For example, Çelik and Açıksöz (2017) examined how sustainability in urban aesthetics can be ensured using urban design guidelines. Crippen (2016) and Mada- nipour (1996) examined urban aesthetics from the perspective of the political aspects of urban design. Mokhtar (2007)'s study criticized the unaesthetic monotony of modern environments through a comparative study. Nasar (1997) evaluated new developments in aesthetics for urban design using historiometric inquiry and aesthetic programming methods. In another study, Dimitrovska Andrews and Butina Watson (2001) performed a critical analysis of successful urban design initiatives to promote high-quality urban design. For this purpose, they proposed basic principles of good urban form at three levels of planning and design: context and general compatibility (site, land use, setting / urban tissue characteristics, and scale), arrangement and external effects (the layout-related quality of the public realm, the quality of physical space, and landscaping), and architecture and detailed design (the most sensitive area of urban design: building types, style, facade/height details, and materials).

The literature review thus demonstrates that the aesthetic assessment of built environments is generally based on the perception and judgment of various aspects of the urban environment. Although aspects as wide-ranging as the aesthetics of residential facades, streetscapes, public space, landscapes, or urban green spaces have been evaluated, the aims of the studies are generally the same. In such studies, the methodologies comprise the selection of case studies, the setting of metric parameters, and the formation of design guidelines for evaluating aesthetic quality. Such studies have also employed public officials, design and planning professionals, architects, and ordinary people in their methodologies. As seen above, studies related to the aesthetic assessment of newly built environments that can provide input to legislation are limited.

\section{Urban design factors in the aesthetic assessment of newly built environments \\ 4.1 Research design}

The research design of this study consists of two stages. In the first stage, the urban design factors involved in the aesthetic assessment of newly built environments are determined and ranked using factor analysis and ANOVA analyses. The second stage examines how these factors can be incorporated into legislation in the case of Istanbul.

Urban aesthetics is mainly related to the external image of an object and place in a given urban context, the position of buildings, and harmony and suitability in composition. The urban design principles used to increase the aesthetic qualities of the built environment have been defined in various ways by different sources (Porteous, 1996; Nasar, 1997; DETR, 
2000; Taylor, 2009; Celik \& Acıksoz, 2017). Among these principles are the urban design parameters of DETR (2000). These parameters have been defined as character ("a place with its own identity"), continuity and enclosure ("a place where public and private spaces are clearly distinguished"), quality of the public realm ("a place with attractive and successful outdoor areas"), ease of movement ("a place that is easy to get to and move through"), legibility ("a place that has a clear image and is easy to understand"), adaptability ("a place that can change easily"), and diversity ("a place with variety and choice"; DETR, 2000: 15). The parameters of this document are used as guidance for best practice and government. A questionnaire was thus prepared taking into consideration the urban design parameters of DETR, as well as the formal parameters obtained from the literature.

The research questionnaire was designed with thirty specific questions to help determine urban design factors in the aesthetic assessment of newly built environments. These questions were divided into three parts. They are presented in greater detail in Section 4.2. The results of the surveys were analysed using the SPSS software (Statistical Package for the Social Sciences) version 21 . The collected survey data were added manually into the SPSS program. Then factor analysis was employed to determine these design factors with consideration paid to the relative importance of their components.

\subsection{Sampling and the database}

The evaluations of experts in urban design areas were required to determine the urban design factors involved in the aesthetic assessment of newly built environments because any parameters must be clearly defined. The terminology involved would not have been clear to the general public or laypeople. Therefore, three groups of experts were selected to participate in the study: scholars, officials, and various urban designers. All the selected participants have lived in Istanbul and are familiar with the situations of newly built environments in the city, especially after the 2000s. Because selecting the entire body of scholars, officials, and designers in fields related to urban design in Istanbul was impossible, a sample was taken to represent them.

Scholars were chosen from the architecture and design departments of universities in Istanbul. According to the Council of Higher Education site (2017), there are fifty universities with thirty-two departments of architecture, interior design, urban design and planning, and landscape architecture in the city. Sixty participants from $5 \%$ of the total department members were engaged as scholar participants.
The second participant group consisted of designers working in design bureaus. Registered design bureaus were selected to provide participants. According to the chambers of architects, planners, and landscape architects in October 2017 there were 102 city planning bureaus, 2,506 architectural design bureaus, and twenty-one landscape architecture bureaus. Thirty-seven participants from $10 \%$ of these offices were selected as designers.

The third participant group consisted of officials working in municipal governments. According to the Istanbul Metropoli$\tan$ Municipality's site, in October 2017 there were thirty-nine district municipalities and one metropolitan municipality. Forty participants, one from each municipality, were selected as officials. The characteristics of all three participant groups are shown in Table 1 .

The survey form consisted of two main sections. The first section of the survey included questions designed to determine the characteristics of the participant groups. The second and main section contained specific questions about urban formal aesthetics. Most of these questions were designed to elicit judgments concerning urban formal aesthetic parameters that could be defined solely by physical attributes. These questions were selected to define more specific formal design parameters on building, design, and planning scales to be included in legislation. This section consisted of three parts and contained questions at the building (design) scale (three-dimensional variables) and the planning scale (two-dimensional variables; see Figure 2). Participants were asked to indicate to what extent they agreed or disagreed with the statements in the survey. The coding of the five-point Likert scale for all questions was as follows: 5 = Strongly Agree, $4=$ Agree, 3 = Neutral, $2=$ Disagree, $1=$ Strongly Disagree. Through this method, the urban design factors involved in the aesthetic assessment of newly built environments were determined in order of importance.

The first twelve questions of the second section concerned aesthetic parameters on building and design scales and three-dimensional design data, including questions about dimension, hierarchy, order, rhythm, proportion, ratio, scale, mass, bulk, architectural motif, solid and void ratio, facade design, form and interior design of buildings, colour, texture, pattern, and materials. Questions 13-18 concerned two- and three-dimensional formal design parameters at both the building (design) and planning scale, emphasizing the most prominent features of newly built environments in recent years, especially in the case of Istanbul: the effects of the predominance of tall buildings, disharmony between building heights, form relationships between buildings, diversity, and ecological landscape design. Questions 18 through 29 concerned planning-scale data, with 
Table 1: Characteristics of participant groups.

\begin{tabular}{|c|c|c|c|c|}
\hline $\begin{array}{l}\text { Participant } \\
\text { characteristics }\end{array}$ & $\begin{array}{l}\text { Scholars } \\
(n=60)\end{array}$ & $\begin{array}{l}\text { Designers } \\
(n=37)\end{array}$ & $\begin{array}{l}\text { Officials } \\
(n=40)\end{array}$ & $\begin{array}{l}\text { Total } \\
(n=137)\end{array}$ \\
\hline \multicolumn{5}{|l|}{ Sex } \\
\hline Female & $42(70 \%)$ & $25(66 \%)$ & $24(60 \%)$ & 91 (34\%) \\
\hline Male & $18(30 \%)$ & $12(34 \%)$ & $16(40 \%)$ & $46(66 \%)$ \\
\hline \multicolumn{5}{|l|}{ Age } \\
\hline $25-30$ & $13(22 \%)$ & $10(27 \%)$ & $6(15 \%)$ & 29 (21\%) \\
\hline $30-35$ & $8(13 \%)$ & $16(43 \%)$ & $13(33 \%)$ & $37(27 \%)$ \\
\hline $35-40$ & $1(1 \%)$ & $1(2 \%)$ & $14(35 \%)$ & $16(12 \%)$ \\
\hline $40-45$ & $13(22 \%)$ & $5(14 \%)$ & $7(17 \%)$ & $25(18 \%)$ \\
\hline Over 45 & $25(42 \%)$ & $5(14 \%)$ & $0(0 \%)$ & $30(22 \%)$ \\
\hline \multicolumn{5}{|l|}{ Position } \\
\hline Architects & $38(64 \%)$ & $19(51 \%)$ & $21(53 \%)$ & 78 (57\%) \\
\hline Interior architects & $6(10 \%)$ & $0(0 \%)$ & $0(0 \%)$ & $6(4 \%)$ \\
\hline Landscape architects & $2(3 \%)$ & $2(5 \%)$ & $2(5 \%)$ & $6(4 \%)$ \\
\hline Urban planners & $12(20 \%)$ & $15(41 \%)$ & $15(37 \%)$ & $42(31 \%)$ \\
\hline Urban designers & $2(3 \%)$ & $1(3 \%)$ & $2(5 \%)$ & $5(4 \%)$ \\
\hline \multicolumn{5}{|l|}{ Monthly income } \\
\hline TL 2,500-3,000 & $8(14 \%)$ & $3(8 \%)$ & $1(3 \%)$ & $12(9 \%)$ \\
\hline TL 3,500-4,500 & $8(14 \%)$ & $10(27 \%)$ & $1(3 \%)$ & $19(14 \%)$ \\
\hline TL 4,500-5,500 & $17(28 \%)$ & $12(32 \%)$ & $25(62 \%)$ & $54(39 \%)$ \\
\hline TL 5,500-6,500 & $10(16 \%)$ & $4(11 \%)$ & $10(25 \%)$ & $24(18 \%)$ \\
\hline Over TL 6,500 & $17(28 \%)$ & $8(22 \%)$ & $3(7 \%)$ & $28(20 \%)$ \\
\hline
\end{tabular}

two-dimensional variables: plot area ratio, grid planning, compatibility between the parcel and surroundings, project-based developments, green design, circulation, and building orientations. The last variable of the survey was the relationship between urban identity and urban aesthetics (Figure 2).

\subsection{Results of the analyses}

In order to evaluate the reliability of the survey scale, a reliability analysis was performed using the SPSS software, which was developed to assess the reliability and authenticity of the tests, surveys, or scales used in measurements. The results of this test are expressed through Cronbach's alpha $(\alpha)$, which in the case of these thirty questions was 0.808 . If $0.80 \leq \alpha \leq 1.00$, then the scale is a reliable measure at a high level (Kalayci, 2005: 405); the test thus indicated a high level of reliability for the survey.

The analysis of variance (ANOVA) revealed that the participants agreed with $87 \%$ of the questions. Table 2 shows the frequencies of parameters on agreeing or disagreeing from the participant responses. The means for each of the three groups for these parameters are shown on the right side of Table 2. ANOVA analysis determined that scholars evaluate urban formal aesthetics differently than officials and designers.
A factor analysis was performed using the SPSS program to determine which urban design factors are the most important in the aesthetic assessment of newly built environments. The aim of this analysis is to reduce the amount of data and to summarize and categorize related parameters in order to more easily interpret and understand relationships and patterns (Yong \& Pearce, 2013: 79). The Kaiser-Meyer-Olkin Measure of Sampling Adequacy was used to test the suitability of research data for factor analysis. The results of the test, with a value of 0.772 , determined that a factor analysis was useful with the given data.

According to the results of the factor analysis in Table 3:

- The first factor (F1) is labelled "character and identity" and accounts for $21.874 \%$ of the common variance. It generally indicates the physical features of buildings and comprises observational measurements of the character or identity of built environments.

- The second factor (F2) is labelled "green design" and accounts for $13.599 \%$ of the common variance. It generally indicates ecological features in planning and design, comprising planning scale measurements for ecological design.

- The third factor (F3) is labelled "incompatibility between identity and design" and accounts for $9.294 \%$ of 


\begin{tabular}{|c|c|c|c|c|c|}
\hline \multicolumn{6}{|c|}{ DEPENDENT VARIABLES } \\
\hline \multicolumn{2}{|c|}{$\begin{array}{l}\text { Building and design scale } \\
\text { (three-dimensional variables) }\end{array}$} & \multicolumn{2}{|c|}{$\begin{array}{l}\text { Building (design) and planning scale } \\
\text { (two- and three-dimension variables) }\end{array}$} & \multicolumn{2}{|c|}{$\begin{array}{l}\text { Planning scale } \\
\text { (two-dimensional variables) }\end{array}$} \\
\hline 1 & $\begin{array}{l}\text { Dimension and continuity have a } \\
\text { positive effect on the urban aesthetic }\end{array}$ & 13 & $\begin{array}{l}\text { Predominance of tall buildings in the } \\
\text { skyline has a negative effect on the } \\
\text { urban aesthetic }\end{array}$ & 19 & $\begin{array}{l}\text { The plot area ratio directly affects the } \\
\text { urban aesthetic }\end{array}$ \\
\hline 2 & $\begin{array}{l}\text { Order and hierarchy have a positive } \\
\text { effect on the urban aesthetic }\end{array}$ & 14 & $\begin{array}{l}\text { Disharmony between building heights } \\
\text { has a negative effect on the urban } \\
\text { aesthetic }\end{array}$ & 20 & $\begin{array}{l}\text { Grid plans have a positive effect on } \\
\text { the urban aesthetic }\end{array}$ \\
\hline 3 & $\begin{array}{l}\text { Proportion, ratio, and rhythm have a } \\
\text { positive effect on the urban aesthetic }\end{array}$ & 15 & $\begin{array}{l}\text { Formal relationships between building } \\
\text { groups have a positive effect on the } \\
\text { urban aesthetic }\end{array}$ & 21 & $\begin{array}{l}\text { Incompatibility between plot and } \\
\text { surroundings identity has a negative } \\
\text { effect on the urban aesthetic }\end{array}$ \\
\hline 4 & $\begin{array}{l}\text { Scale, mass, and bulk have a positive } \\
\text { effect on the urban aesthetic }\end{array}$ & 16 & $\begin{array}{l}\text { Uniform type of mass housing has a } \\
\text { negative effect on the urban aesthetic }\end{array}$ & 22 & $\begin{array}{l}\text { Incompatibility of project-based de- } \\
\text { velopments with detailed local plans } \\
\text { has a negative effect on the urban } \\
\text { aesthetic }\end{array}$ \\
\hline 5 & $\begin{array}{l}\text { Architectural motif repetition has a } \\
\text { positive effect on the urban aesthetic }\end{array}$ & 17 & $\begin{array}{l}\text { Diversity and visual wealth have a } \\
\text { positive effect on the skyline }\end{array}$ & 23 & $\begin{array}{l}\text { Green areas have a positive effect on } \\
\text { the urban aesthetic }\end{array}$ \\
\hline 6 & $\begin{array}{l}\text { Solid and void ratio in the facade } \\
\text { design has a positive effect on the } \\
\text { urban aesthetic }\end{array}$ & 18 & $\begin{array}{l}\text { Ecological landscape design has a posi- } \\
\text { tive effect on the urban aesthetic }\end{array}$ & 24 & $\begin{array}{l}\text { Integration with the main pedestrian } \\
\text { paths has a positive effect on the } \\
\text { urban aesthetic }\end{array}$ \\
\hline 7 & $\begin{array}{l}\text { Facade-mass mismatch with local } \\
\text { land-use plans has a negative effect } \\
\text { on the urban aesthetic }\end{array}$ & & & 25 & $\begin{array}{l}\text { Disharmony between building height } \\
\text { and path width has a negative effect } \\
\text { on the urban aesthetic }\end{array}$ \\
\hline 8 & $\begin{array}{l}\text { The incompatibility of form with } \\
\text { structure has a negative effect on the } \\
\text { urban aesthetic }\end{array}$ & & & 26 & $\begin{array}{l}\text { Closed and isolated design has a neg- } \\
\text { ative effect on the urban aesthetic }\end{array}$ \\
\hline 9 & $\begin{array}{l}\text { Colour harmony between buildings } \\
\text { has a positive effect on the urban } \\
\text { aesthetic }\end{array}$ & & & 27 & $\begin{array}{l}\text { Solid and void ratio between build- } \\
\text { ings has a positive effect on the ur- } \\
\text { ban aesthetic }\end{array}$ \\
\hline 10 & $\begin{array}{l}\text { Incompatibility of textures, patterns, } \\
\text { and materials has a negative effect } \\
\text { on the urban aesthetic }\end{array}$ & & & 28 & $\begin{array}{l}\text { Lack of protection for the natural } \\
\text { environment and ecosystem has a } \\
\text { negative effect on the urban aesthetic }\end{array}$ \\
\hline 11 & $\begin{array}{l}\text { Building interior design has an effect } \\
\text { on the urban aesthetic }\end{array}$ & & & 29 & $\begin{array}{l}\text { The proper orientation of the build- } \\
\text { ings has a positive effect on the ur- } \\
\text { ban aesthetic }\end{array}$ \\
\hline 12 & $\begin{array}{l}\text { The use of ecological materials has a } \\
\text { positive effect on the urban aesthetic }\end{array}$ & & & 30 & $\begin{array}{l}\text { The creation of urban identity } \\
\text { through urban aesthetics }\end{array}$ \\
\hline
\end{tabular}

Figure 2: Dependent variables: questions used in the survey.

the common variance. It generally indicates plot features in planning and design, and it comprises planning and building scale measurements in the built environment.

- The fourth factor (F4) is labelled "lack of protection for continuity and the natural environment" and accounts for $5.569 \%$ of the common variance. It generally indicates plot features in design and comprises planning scale measurements for the built environment.

- The fifth factor (F5) is labelled "tall buildings" and accounts for $5.235 \%$ of the common variance. It generally indicates the planning features in built environments.

- The sixth factor (F6) is labelled "plan-based versus project-based development" and accounts for $4.176 \%$ of the common variance. In Turkey, urban planning is prac- ticed through a regulatory planning system. Although grid planning is often used, project-based developments outside of the existing planning system have increased, especially since 2000 (Ozkan \& Turk, 2016). F6 generally indicates the planning features in built environments.

- The seventh factor (F7) is labelled "harmony between groups of buildings" and accounts for $3.942 \%$ of the common variance. It generally indicates planning features in built environments.

- The eighth and last factor (F8) is labelled "building interior design" and accounts for $3.857 \%$ of the common variance. It generally indicates the building features in built environments. 
Table 2: Results of the analysis of variance.

\begin{tabular}{|c|c|c|c|c|c|c|c|}
\hline \multirow[t]{2}{*}{ Variables } & \multicolumn{2}{|c|}{ Agree } & \multicolumn{2}{|c|}{ Disagree } & \multicolumn{3}{|l|}{ Means } \\
\hline & $n$ & $\%$ & $n$ & $\%$ & Scholars & Officials & Designers \\
\hline 1 & 55 & 40.1 & 68 & 49.7 & 2.40 & 3.62 & 3.24 \\
\hline 2 & 79 & 57.7 & 42 & 30.6 & 3.85 & 2.72 & 3.08 \\
\hline 3 & 84 & 61.3 & 36 & 26.3 & 3.91 & 2.92 & 3.35 \\
\hline 4 & 69 & 50.4 & 44 & 32.1 & 3.78 & 2.32 & 3.02 \\
\hline 5 & 34 & 24.8 & 55 & 40.2 & 3.10 & 2.35 & 2.62 \\
\hline 6 & 62 & 30.3 & 50 & 36.5 & 3.20 & 2.90 & 2.94 \\
\hline 7 & 108 & 78.9 & 12 & 8.7 & 4.23 & 3.90 & 4.10 \\
\hline 8 & 111 & 81.0 & 12 & 8.8 & 4.26 & 4.20 & 3.91 \\
\hline 9 & 61 & 44.5 & 40 & 29.1 & 3.41 & 3.05 & 2.86 \\
\hline 10 & 103 & 75.8 & 10 & 7.3 & 3.98 & 3.85 & 4.38 \\
\hline 11 & 35 & 25.6 & 72 & 52.6 & 2.30 & 2.80 & 2.89 \\
\hline 12 & 66 & 48.2 & 40 & 29.2 & 2.90 & 3.72 & 3.43 \\
\hline 13 & 121 & 88.3 & 6 & 4.3 & 4.43 & 4.45 & 4.16 \\
\hline 14 & 123 & 89.8 & 9 & 6.6 & 4.36 & 4.65 & 4.18 \\
\hline 15 & 77 & 56.6 & 14 & 10.3 & 3.81 & 3.56 & 3.27 \\
\hline 16 & 110 & 80.3 & 12 & 8.8 & 4.33 & 4.02 & 3.94 \\
\hline 17 & 72 & 52.6 & 38 & 27.7 & 3.88 & 2.70 & 3.10 \\
\hline 18 & 97 & 70.8 & 17 & 12.4 & 3.98 & 3.82 & 4.08 \\
\hline 19 & 113 & 82.5 & 7 & 5.1 & 4.21 & 4.27 & 4.05 \\
\hline 20 & 45 & 33.1 & 44 & 32.3 & 3.31 & 2.89 & 2.51 \\
\hline 21 & 114 & 83.2 & 6 & 5.8 & 4.20 & 4.15 & 4.21 \\
\hline 22 & 105 & 76.7 & 9 & 6.5 & 4.25 & 4.17 & 3.86 \\
\hline 23 & 102 & 74.5 & 16 & 11.7 & 4.20 & 3.80 & 4.02 \\
\hline 24 & 94 & 68.6 & 24 & 17.5 & 3.46 & 3.95 & 3.91 \\
\hline 25 & 114 & 83.2 & 10 & 7.3 & 4.13 & 4.45 & 4.35 \\
\hline 26 & 98 & 71.6 & 13 & 9.5 & 4.05 & 4.05 & 3.97 \\
\hline 27 & 88 & 64.2 & 31 & 22.6 & 3.91 & 3.25 & 3.40 \\
\hline 28 & 119 & 86.8 & 7 & 5.1 & 4.20 & 4.37 & 4.56 \\
\hline 29 & 78 & 56.9 & 32 & 23.4 & 3.30 & 3.77 & 3.72 \\
\hline 30 & 104 & 75.9 & 17 & 12.4 & 4.30 & 3.90 & 3.86 \\
\hline
\end{tabular}

\subsection{Urban design factors for aesthetic assessment of newly built environments in existing legislation}

According to the results of the factor analysis, "character and identity" is the first and most important parameter that affects urban formal aesthetics. This factor is followed by the factors of green design, incompatibility between design and identity, lack of protection for continuity and the natural environment, tall buildings, plan-based versus project-based development, harmony between building groups, and building interior design. Whether these factors are present in the existing legislation is examined below.
Legislation related to aesthetic assessment can be divided into three levels in Turkey and Istanbul: the national level, the city/ town level, and the local level (see Figure 3).

The articles related to urban design and aesthetics that concern land plots, paths, structures, and the skyline are summarized in Figure 4. The relationships between these laws and the eight determined factors are shown in Figure 5, which shows the laws and regulations containing provisions related to the eight factors. It also tries to show current legal approaches to the problems related to these factors.

A consideration of the legislation related to newly built environments along with a comparison of Figure 4 and Figure 5 
Table 3: Factors and parameters.

\begin{tabular}{|c|c|}
\hline Factor analysed & Factor content \\
\hline \multirow{9}{*}{ F1: Character and identity } & 1. Proportion, ratio, rhythm \\
\hline & 2. Scale, mass, bulk \\
\hline & 3. Order, hierarchy \\
\hline & 4. Dimension and continuity \\
\hline & 5. Diversity and visual wealth \\
\hline & 6. Solid and void ratio in facade design \\
\hline & 7. Colour harmony \\
\hline & 8. Architectural motif \\
\hline & 9. Urban identity \\
\hline \multirow{5}{*}{ F2: Green design } & 1. Ecological landscape design \\
\hline & 2. Integration with the main pedestrian path \\
\hline & 3. Use of ecological materials \\
\hline & 4. Proper orientation of buildings \\
\hline & 5. Green areas \\
\hline \multirow{5}{*}{ F3: Incompatibility between identity and design } & 1. Incompatibility between the forms of structures \\
\hline & 2. Relationship between parcel and building \\
\hline & 3. Plot and surroundings identity \\
\hline & 4. Texture/pattern/material relationships \\
\hline & 5. Uniform mass housing \\
\hline \multirow{3}{*}{$\begin{array}{l}\text { F4: Lack of protection for continuity and the natural envi- } \\
\text { ronment }\end{array}$} & 1. Building height / road width \\
\hline & 2. Lack of protection for the natural environment and ecosystem \\
\hline & 3. Closed and isolated design \\
\hline \multirow{2}{*}{ F5: Tall buildings } & 1. Building height / road width \\
\hline & 2. Effects of the predominance of tall buildings \\
\hline \multirow{2}{*}{ F6: Plan-based versus project-based development } & 1. Incompatibility of project-based development with detailed local plans \\
\hline & 2. Grid plan \\
\hline F7: Harmony between groups of buildings & 1. Relationships between groups of buildings \\
\hline F8: Interior design & 1. Building interior design \\
\hline
\end{tabular}

\section{LEGISLATION RELATED TO AESTHETIC ASSESSMENT}

\begin{tabular}{|l|}
\hline National level \\
Development Law no. 3194 \\
Regulation on Planned Areas \\
of Spative on the Preparation \\
Special-purpose laws \\
Administrative laws
\end{tabular}

Province/municipal level
Municipal development regulations
Top-level land-use plans
Local land-use plans
Local land-use plan notes

\section{Local level}

Detailed local plans

Detailed local plan notes

Design guidelines

Architectural aesthetics committee decisions

Figure 3: Legislation related to aesthetic assessment in Turkey. 


\begin{tabular}{|c|c|c|}
\hline \multicolumn{3}{|c|}{ Articles related to urban design and aesthetics in the urban laws and regulations on newly built environments (the case of Istanbul) } \\
\hline Laws and regulations & Articles related to urban design and aesthetic & \\
\hline \multirow{4}{*}{ Land development laws and regulations } & Development Law & $\begin{array}{l}\text { Forms, plot and expropriation, land readjustment, } \\
\text { setback from the street, facade size, height }\end{array}$ \\
\hline & Regulation on Planned Areas & $\begin{array}{l}\text { Standards about plot size and depth, standards } \\
\text { about yard distance from the road, buildings } \\
\text { depth and height, facade principles, construction } \\
\text { standards, the effect of facades on the character } \\
\text { of the area, number of floors and height }\end{array}$ \\
\hline & Directive on the Preparation of Spatial Plans & $\begin{array}{l}\text { Standards about different area size, width of } \\
\text { the pedestrian and vehicle ways, urban design } \\
\text { guidelines }\end{array}$ \\
\hline & Istanbul Development Regulation & $\begin{array}{l}\text { Forms, plot standards for yard distance from the } \\
\text { road, construction standards }\end{array}$ \\
\hline \multirow{4}{*}{ Special-purpose laws } & Environmental Law & $\begin{array}{l}\text { Sustainable development, protecting the envi- } \\
\text { ronment }\end{array}$ \\
\hline & Mass Housing Law & Plot and expropriation, sustainable development \\
\hline & Tourism Promotion Law & $\begin{array}{l}\text { Sustainable development, protecting the envi- } \\
\text { ronment }\end{array}$ \\
\hline & $\begin{array}{l}\text { Law on Restructuring Areas at Risk of Natu- } \\
\text { ral Disasters }\end{array}$ & $\begin{array}{l}\text { Plot, land adjustment, sustainable development, } \\
\text { protecting the environment }\end{array}$ \\
\hline \multirow{2}{*}{ Administrative laws } & Metropolitan Municipality Law & $\begin{array}{l}\text { Creating harmony within the plan, building } \\
\text { facades, standards for streets and boulevards, } \\
\text { standards for advertisements' size and shape }\end{array}$ \\
\hline & Municipal Law & $\begin{array}{l}\text { Standards for advertisements' size and shape, } \\
\text { land and house development, regular urbaniza- } \\
\text { tion. }\end{array}$ \\
\hline \multirow[t]{2}{*}{ Other legal tools } & $\begin{array}{l}\text { Architectural aesthetics committee's princi- } \\
\text { ples }\end{array}$ & $\begin{array}{l}\text { Deciding whether architectural projects express } \\
\text { original ideas (According to the Development } \\
\text { Law, relevant authorities can establish an ar- } \\
\text { chitectural aesthetics committee based on the } \\
\text { guidelines set by the ministry) }\end{array}$ \\
\hline & Design guidelines & Form, plot, width of streets, skyline \\
\hline
\end{tabular}

Figure 4: Articles related to urban design and aesthetics in Istanbul.

\begin{tabular}{|c|c|c|c|}
\hline \multicolumn{2}{|c|}{ Legal tools in the case of Istanbul } & \multicolumn{2}{|c|}{$\begin{array}{l}\text { Relations between laws and regulations, and the eight factors } \\
\text { established }\end{array}$} \\
\hline & & None & Partly \\
\hline \multirow{5}{*}{$\begin{array}{l}\text { Land development laws } \\
\text { and regulations }\end{array}$} & Development Law & $F 2, F 3, F 4, F 7, F 8$ & F1, F5, F6 \\
\hline & Regulation on Planned Areas & F3, F7, F8 & F1, F2, F4, F5, F2, F6 \\
\hline & $\begin{array}{l}\text { Directive on the Preparation of Spatial } \\
\text { Plans }\end{array}$ & F1, F4, F7, F8 & F2, F3, F5, F6 \\
\hline & Istanbul Development Regulation & F7, F8 & F1, F2, F3, F4, F5, F6 \\
\hline & Plan notes & F3, F4, F5, F6, F7, F8 & $F 1, F 2$ \\
\hline \multirow{4}{*}{ Special-purpose laws } & Environmental Law & F1, F2, F3, F5, F6, F7, F8 & F4 \\
\hline & Mass Housing Law & F5, F6, F7, F8 & $F 1, F 2, F 3, F 4$ \\
\hline & Tourism Promotion Law & F2, F3, F4, F5, F6, F7, F8 & F1 \\
\hline & $\begin{array}{l}\text { Law on Restructuring Areas at Risk of } \\
\text { Natural Disasters }\end{array}$ & F3, F4, F5, F6, F7, F8 & $F 1, F 2$ \\
\hline \multirow{2}{*}{ Administrative laws } & Metropolitan Municipality Law & F1, F3, F5, F6, F7, F8 & $\mathrm{F} 2, \mathrm{~F} 4$ \\
\hline & Municipal Law & F1, F3, F5, F6, F7, F8 & $\mathrm{F} 2, \mathrm{~F} 4$ \\
\hline \multirow[t]{2}{*}{ Other legal tools } & $\begin{array}{l}\text { Architectural aesthetics committee } \\
\text { principles }\end{array}$ & F2, F5, F6, F7, F8 & $\mathrm{F} 1, \mathrm{~F} 3, \mathrm{~F} 4$ \\
\hline & Design guidelines & F7, F8 & F1, F2, F3, F4, F5, F6 \\
\hline
\end{tabular}

Figure 5: Relations between laws and regulations on newly built environments and the eight established factors in Istanbul. 
demonstrates that most of these legal approaches give a general description of these factors. For example, there are some general articles in the Development Law (Tur. İmar Kanunu) and its provisions concerning scale, mass, facade design, colour harmony, and ecological landscape, all of which are related to Factor 1 (character and identity). Some of the other parameters can be found in the Directive on the Preparation of Spatial Plans, referred to as "design guidelines". Similar references can be found in the special-purpose laws, administrative laws, and other legal tools. These brief appearances demonstrate the fragmentary nature of various provisions concerning issues of urban formal aesthetics, with no detailed statements about how the urban formal aesthetic for newly built environments must be created. In general, it can be said that there are no detailed legal tools related to urban formal aesthetics.

\section{Conclusion}

In the reconfiguration of urban spaces under neoliberal policies and priorities, changing urban features have been criticized for their lack of aesthetic quality. This situation, especially after the 2000s, has affected the newly built environments because the identity and texture of these areas were not taken into account in the plan. The concept of urban aesthetics has thus become much more important in this period. Although there are many studies concerning urban aesthetics, studies of urban formal aesthetics related to newly built environments are very rare. In this study, the most important factors affecting urban formal aesthetics have been determined using factor analysis, revealing which factors are lacking in the legislation and should be added to in order to regulate formal urban aesthetics in newly built environments. A comparison of these factors in the case of Istanbul demonstrates that there are fragmented articles inside different laws related to urban aesthetics, and that there are serious shortcomings concerning some factors in the legislation.

Moreover, this analysis demonstrates which factor components should be added in the legislation, and to what extent. Although some of the parameters are general, others are detailed. These parameters, in accordance with their scope, can be incorporated into legislation at the national level, city/town level, and local level. The parameters "character and identity" (F1), "green design" (F2), "protection of continuity and the natural environment" (F4), "tall buildings" (F5), and "consistency between plan-based and project-based development" (F6) are generally issues at the national level that should be added to the Development Law and special-purpose laws. Parameters such as "proportion, scale, hierarchy, dimension, diversity" (F1), "form of structures" (F3), and "building height / road width" (F5) should be added to the Development Law and its provisions at a general level, and "solid and void ratio in facade design, colour harmony, architectural motif" (F1), "ecological landscape design, integration with the main pedestrian path, proper orientation of buildings, green areas, ecological materials" (F2), "texture/pattern and materials" (F3), "building height / road width, controlling the effect of the predominance of tall buildings" (F5), "relationships between building groups" (F7), and "building interior design" (F8) are the subjects of detailed local plans and related plan notes, as well as design guidelines and the decisions of architectural aesthetic commissions at the local level. The parameter "project-based developments, grid plan, compatibility of project-based developments with detailed local plans" (F6) should be provided for in the Development Law. Likewise, "uniform mass housing" (F3) is a current problem that should be solved in the Mass Housing Law (a type of special-purpose law) at the national level. The parameter "protecting the natural environment and ecosystem" (F4) can be added to the Municipal Law at the national level. The parameters "urban identity" (F1) and "relationship between parcel and building, plot and surroundings identity" (F3) are issues at the city/town level that should be added to top-level land-use plans, local land-use use plans, and detailed local plans and their plan notes. However, most importantly, there should be compatibility between these laws and regulations. Another important subject is the capacity, level, and planning and design knowledge of professionals involved in planning and design processes. These should be consistent with each other in giving instructions, implementation, and management. As the analysis has pointed out, scholars' views in evaluating urban formal aesthetics are different from those of officials and designers.

These goals can be achieved by paying attention to and applying these parameters on both building design and planning scales in newly built environments. There is a significant need for the rearrangement of legislation, especially in the case of cities like Istanbul, which is Turkey's most important economic, cultural, and tourism centre. The knowledge gained from the Istanbul case may be useful for other countries facing the same dynamic development processes in their cities.

\section{Azadeh Rezafar}

Istanbul Arel University, Faculty of Civil Engineering and Architec-

ture, Department of Architecture, Istanbul, Turkey

E-mail: azadehrezafar@arel.edu.tr

Sevkiye Sence Turk

Istanbul Technical University, Faculty of Architecture, Department of Urban and Regional Planning, Istanbul, Turkey

E-mail: turkss@itu.edu.tr 


\section{References}

Ahmad Nia, H., Alpar Atun, R. \& Rahbarianyazd, R. (2017) Perception based method for measuring the aesthetic quality of the urban environment. Open House International, 42(2), pp. 11-19.

Balaban, O. (2012) The negative effects of construction boom on urban planning and environment in Turkey: Unraveling the role of the public sector. Habitat International, 36(1), pp. 26-35.

DOI: 10.1016/j.habitatint.2011.05.003

Barfu Candan, A. \& Özbay, C. (2014) Yeni İstanbul çalışmaları: sınırlar, mücadeleler, açılımlar. Istanbul, Metis Yayınları.

Cats-Baril, W. \& Gibson, L. (1987) Evaluating landscape aesthetic: A multi-attribute utility approach. Landscape and Urban Planning, 14, pp. 463-480. DOI: 10.1016/0169-2046(87)90060-0

Celik, D. \& Acıksoz, S. (2017) Urban aesthetic and urban landscape design guides: A case study of Bartin-Turkey. Journal of Environmental Biology, 38(5), pp. 893-901. DOI: 10.22438/jeb/38/5(SI)/GM-04

Chen, B., Adimo, O. \& Bao, Z. (2009) Assessment of aesthetic quality and multiple functions of urban green space from the users' perspective: The case of Hangzhou Flower Garden, China. Landscape and Urban Planning, 93(1), pp. 76-82. DOI: 10.1016/j.landurbplan.2009.06.001

Council of Higher Education (2017) Available at: http://www.yok.gov.tr/ web/guest/universitelerimiz (accessed 16 Oct. 2017).

Crippen, M. (2016) Intuitive cities: Pre-reflective, aesthetic and political aspects of urban design. Journal of Aesthetics and Phenomenology, 3(2), pp. 125-145. DOI: 10.1080/20539320.2016.1256067

DETR (2000) By design. Urban design in the planning system: Toward better practice. London, Commission for Architecture and the Built Environment.

Dimitrovska Andrews, K. \& Butina Watson, G. (2001) City urban design in a free market economy - The case of Ljubljana, Slovenia. Urban Design International, 6(3-4), pp. 143-155.

DOI: $10.1057 /$ palgrave.udi.9000054

Erdoğan, E. (2006) Çevre ve kent estetiği. ZKÜ Bartın Orman Fakültesi Dergisi, 8(9), pp. 68-77.

Gjerde, M. (2018) Visual aesthetic perception and judgement of urban streetscapes. Available at: http://www.irbnet.de/daten/iconda/CIB18896. pdf (accessed 24 Oct. 2018).

Gomeshi, M. \& Mohd Jusan, M. (2013) Investigating different aesthetic preference between architects and non-architects in residential façade designs. Indoor and Built Environment, 22(6), pp. 952-964. DOI: $10.1177 / 1420326 \times 12458513$

GYODER (2015) A new vision for growth. Restructuring of Istanbul: Reconnection, regeneration, resettlement, pp. 2-4. Istanbul, Cumhuriyet Caddesi Pegasus Evi.

Husukic, E. \& Zejnilovic, E. (2017) The environmental aesthetics of Sarajevo: A city shaped by memory. Urbani izziv, 28(1), pp. 96-106. DOI: 10.5379/urbani-izziv-en-2017-28-01-002

Karaman, O. (2013) Urban renewal in Istanbul: Reconfigured spaces, robotic lives. International Journal of Urban and Regional Research, 37(2), pp. 715-733. DOI: 10.1111/j.1468-2427.2012.01163.x

King, J. (1997) Aesthetics in integrated conservation planning. Urban space and urban conservation as an aesthetic problem. In: Algreen-Ussing, G., Bek, L., Frandsen, S. B. \& Schjerup-Hansen, J. (eds.) Aesthetics in integrated conservation planning: A consideration of its value, pp. 19-26. Rome, L'Erma di Bretschneider.
Kuban, D. \& Yalçın, E. (2010) Istanbul: An urban history: Byzantion, Constantinopolis, Istanbul. Istanbul, Türkiye İş Bankası Kültür Pub.

Kuyucu, T. \& Ünsal, Ö. (2010) Urban transformation as state-led property transfer: An analysis of two cases of urban renewal in Istanbul. Urban Studies, 47(7), pp. 1479-1499. DOI: 10.1177/0042098009353629

Lovering, J. \& Turkmen, H. (2011) Bulldozer neo-liberalism in Istanbul: The state-led construction of property markets, and the displacement of the urban poor. International Planning Studies, 16(1), pp. 73-96. DOI: $10.1080 / 13563475.2011 .552477$

Madanipour, A. (1996) Design of urban space: An inquiry into a socio-spatial process. Chichester, UK, John Wiley \& Sons.

Mokhtar, M. (2007) Aesthetic values in urban design, case study Constantine. Doctoral thesis. Constantine, University of Mentouri, Department of Architecture and Urban Planning.

Mowla, Q. A. (2011) Urban aesthetics: A study on Dhaka. In: Sharifuddin, A., Hafiz, R. \& Golam Rabbani A. K. M. (eds.) The history heritage and urban issues of capital Dhaka, volume-III, urbanization and urban development, pp. 169-262. Dhaka, Asiatic Society of Bangladesh.

Munasinghe, H. (2016) Aesthetics of urban space through collaborative urban planning: Integrating environmental aesthetics with communicative theory of planning. Built-Environment Sri Lanka, 2(1), pp. 35-44. DOI: 10.4038/besl.v2i1.7629

Nasar, J. L. (1990) The evaluative image of the city. Journal of the American Planning Society, 56(1), pp. 41-53. DOI: $10.1080 / 01944369008975742$

Nasar, J. L. (1994) Urban design aesthetics: The evaluative qualities of building exteriors. Environment and Behavior, 26(3), pp. 377-401. DOI: $10.1177 / 001391659402600305$

Nasar, J. L. (1997) New developments in aesthetics for urban design. Urban Design Aesthetics, Advances in Environment, Behavior, and Design, 4, pp. 149-193. DOI: 10.1007/978-1-4757-4425-5_5

Norton, T. M. (1967) Police power, planning and aesthetics. Santa Clara Lawyer, 7(2), pp. 171-187.

Onaran, K. (1995) Protecting the collectively appreciated: Different approaches to aesthetics and aesthetic regulation in the United States. METUJFA, 15(1-2), pp. 17-36.

Özalp, S. \& Erkut, G. (2016) Kamu yararı perspektifinden İstanbul'da kentsel müdahaleler. Planlama, 26(3), pp. 242-245.

Ozkan, H. \& Turk, S. S. (2016) Emergence, formation and outcomes of flexibility in Turkish planning practice. IDPR, 38(1), pp. 25-54. DOI: 10.3828 /idpr.2016.2

Pehlivanoğlu, Y. (2011) Understanding perceptions regarding the aesthetics of urban public space: Tunalı Hilmi Street, Ankara. Master's thesis. Ankara, Middle East Technical University.

Porteous, J. D. (1996) Environmental aesthetics: Ideas, politics and planning, London, Routledge.

Sahraoui, Y., Clauzel, C. \& Foltete, J. C. (2016) Spatial modelling of landscape aesthetic potential in urban-rural fringes. Journal of Environment Management, (181), pp. 623-636. DOI: 10.1016/j.jenvman.2016.06.031

Sleegers, F. (2014) Linear infiltration systems along urban streets: Evaluating aesthetic values. Journal of Landscape Architecture, 9(1), pp. 48-59. DOI: $10.1080 / 18626033.2014 .898831$

Sternberg, R. (1991) The urban aesthetic in comparative perspective. In: Environmental, Urban and Geographic Studies, pp. 70-79. Upper Montclair, NJ, Montclair State College. 
Swyngedouw, E., Moulaert, F. \& Rodriguez, A. (2002) Neoliberal urbanization in Europe: Large-scale urban development projects and the new urban policy, Antipode, 34(3), pp. 547-582. DOI: 10.1111/14678330.00254

Taylor, N. (2009) Legibility and aesthetics in urban design. Journal of Urban Design, 14(2), pp. 189-202. DOI: 10.1080/13574800802670929

Teymur, N. (1981) Aesthetics of aesthetic, aesthetic question in architectural and urban discourses. M.E.T.U. Journal of the Faculty of Architecture, 7(1), pp. 77-96.

Thibaud, J. (2010) La ville à l'épreuve des sens. In: Coutard, O. \& Lévy, J. P. (eds.) Ecologies Urbaines, pp. 198-213. Paris, Editions Economica.

Verdi, L. (2014) Aesthetics in urban space: Architecture and art for sustainable cities. Social Space Journal, 10(12), pp. 1-18.

Xianghan, C. (2008) Urban images and urban aesthetics, urban aesthetics in cross cultural perspectives. EFD/JFL, Journal of Faculty of Letters, 25(2), pp. 59-71.

Yong, A. G. \& Pearce, S. (2013) A beginner's guide to factor analysis: Focusing on exploratory factor analysis. Tutorials in Quantitative Methods for Psychology, 9(2), pp. 79-94. DOI: 10.20982/tqmp.09.2.p079 